\title{
RELATIVE EFFECTIVENESS BETWEEN JASMINE FLOWER COMPRESS AND COLD COMPRESS ON PAIN INTENSITY AND TIME REDUCTION IN THE BREAST MILK WEANING PROCESS
}

\author{
Arifah Istiqomah, Tita Restu Yuliasri \\ Academy of Midwifery Ummi Khasanah
}

\begin{abstract}
Background: Breast milk is the optimal form of nutrition in infancy. Weaning from the breast is a natural, inevitable stage in a child's development. It is a complex process involving nutritional, immunological, biochemical and psychological adjustments. Jasmine oil has a stimulating effect on the nervous system function. Jasmine essential oils stimulate the body to release endorphins which are natural pain killers and mood enhancer. Cold compress when applied can decrease the amount of blood collecting around a wound, which can reduce bruising, swelling, inflammation and acute pain. The purpose of this study was to determine relative effectiveness between jasmine flower compress and cold compress on pain intensity and time reduction in the breast milk weaning process.
\end{abstract}

Subjects and Method: This was a quasi-experiment with pretest and posttest nonequivalent control group. The study was conducted at Pundong integrated health center, Bantul, Yogyakarta. A sample of 80 breastfeeding mothers was selected for this study and divided into two groups: jasmine flower compress group and cold compress group. The dependent variables were pain intensity and pain duration. The independent variables were jasmine flower compress and cold compress. The data were measured by numeric rating scale (NRS) and analyzed by t-test.

Results: Pain intensity reduction was larger in the intervention group (1.85) than the control group (0.93), and it was statistically significant $(\mathrm{p}=0.001)$. Pain duration was shorter in the intervention group (3 days) than the control group ( 5 days), and it was statistically significant $(\mathrm{p}=0.001)$.

Conclusion: Jasmine compress is more effective in both reducing pain intensity and pain duration than cold compress.

Keywords: jasmine flower compress, cold compress, pain intensity, pain duration, breast feeding, weaning

\section{Correspondence:}

Arifah Istiqomah. Ummi Khasanah Midwifery Academy, Jl. Pemuda, Gandekan, Bantul 55711, Yogyakarta.E-mail: ariifaah@gmail.com. Mobile: 085702050670

The 5th International Conference on Public Health Best Western Premier Hotel, Solo, Indonesia, February 13-14, 2019 | 306

https://doi.org/10.26911/theicph.2019.03.44 